\title{
The Teacher's Perception on TPM-Kurtilas Implementation in Amal Keluarga Kindergarten- Bandung
}

\author{
Aan Listiana, Yeni Rachmawati \\ Department of Early Childhood Education, Universitas Pendidikan Indonesia, Indonesia \\ Corresponding e-mail: aanlistiana@gmail.com
}

\begin{abstract}
This study aims to obtain data on the teacher's perception of the implementation program of character development through the Teaching Pyramid Model based on 2013 curriculum (TPM-Kurtilas). The data required as an input for improvement because the program is still a pilot study project. The data was obtained through interviews with principals and two teachers. In addition, the data also obtained by teacher's fieldnote when implementing the TPM-Kurtilas program. The research method uses descriptive analysis with thematic analysis technique. The results showed that the teacher's perceptions are generally positive and hope this TPM-Kurtilas is being continued. They found that the most prominent's behavior after this TPM-Kurtilas implementation is the children become more independence, orderly and tidy. The teachers also stated that the design of learning environment (classroom setting) make the children comfortable and the children's enthusiasm for learning improved. Besides that, the presence of various rules posters help children to obey the rules. In general, it can be concluded that TPM-Kurtilas program gives some benefit and helpful in improving independence, orderly and children'studiness.
\end{abstract}

Keywords: $\quad$ TPM-Kurtilas TPM-Kurtilas, Early Childhood, Kindergarten's Teacher, Basic Character, Independence, orderly

\section{INTRODUCTION}

Character building is one of the main objectives to be achieved in the provision of education in Indonesia. Moreover, it becomes the first mission in realizing the national development mission in accordance with UUD 1945 and Law no. 17 of 2007. National character that become a priority through this education is a man who is faithful and righteous, noble, healthy, knowledgeable, skilled, creative, independent, and become democratic and responsible citizens (UUSPN 2003 chapter 2 section 3 ). In order to reach these objectives, education must embody this national character in the form of creating the atmosphere of learning process as systematic and as planned well (UUSPN 2003 chapter 1 article 1, paragraph 1 and 2). From now on this educational objectives have already mentioned in 2013 curriculum in which for basic education's content, $80 \%$ is for character education portion and $20 \%$ for knowledge or academic portion (Circular of 2013 curriculum).
However, this objective has not been fully realized, there are still many children who do not adapt to the expected appropriate character. The fact says that in Indonesia a number of behavioural problems among children and adolescents is still high reaching 21.689.987 cases in 33 provinces and 22 districts of the city (KPAI, 2014). Another problem is that the teachers are still confused and need practical guidance to implement character education in schools. Regarding to this children's behaviour problem only focus on habituation activities and so incidental action in a manner of children's reminiscent if they behave as unexpected as teachers hope (Listiana, 2013).

Besides that the focus of kindergarten's instruction is generally dominated by cognitive aspects that is why the character development in kindergarten still low (Olim, A., 2010; Humaida, 2013; Ratnasari, 2015). The knowledge of Character development also generally have untouched on practical aspects of everyday life (Muhtadi, A. 2010; Nurchotimah, 2013; Setiawan, 2013; Wardani, K., 2010; Wiyono, H, 2012; Nata, A. 2013). 
One program that could be expected to solve the above problems is a TPM-Kurtilas program (Listiana \& Rachmawati, 2016). The program is the adaptation of Teaching Pyramid Model initiated by Fox, et.al. (2010) combined with 2013 curriculum. Below is an overview of TPM-Kurtilas program used in this study:

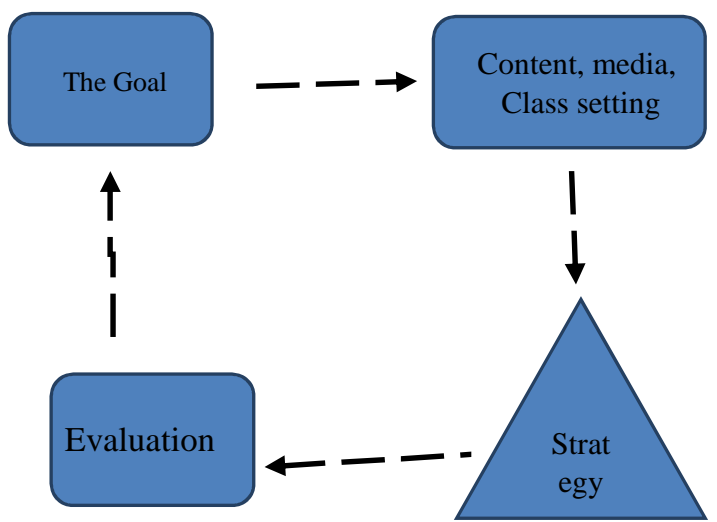

Figure 1. Model TPM -Kurtilas (Listiana \& Rachmawati, 2016)

The concept, stages, and strategies in TPMKurtilas are refered to the TPM developed by Fox, L. (2010). The difference is in the formulation of the goals, objectives, and materials that taken from 2013 curriculum. The provision of media and classroom setting are also done based on the needs and adapted to its local culture. There are four stages include into this children's basic character development: building positive relationship between teachers and pupils, setting a conducive learning environment, using teaching strategies, and providing an intensive individual intervention (Fox, L., et.al., 2003). The TPM actually has been through a series of research conducted by Fox, et.al. or by other researchers with diverse research focus. Here is a study related to TPM conducted by Fox, et.al, and other researchers from 2003 - 2010: The Effect of TPM on building social competence and preventing the emergence of challenging behaviour in early childhood (Fox, et.al., 2003); The Effect of TPM on Socialemotional skills (Fox, L. \& Lentini, R.H., 2006); The Effect of TPM on Social, emotional, and children's school readiness (Hemmeter, M.L., et al, 2006); TPM's Training for Teachers and Professionals (Fox, L., et.al, 2009\&Hemmeter, M.L., et.al, 2011), TPM as a response to intervention (Fox, et.al, 2010); TPM Implementation in Toddler Level (Branson, D. \& Demchack, M, 2010).

Meanwhile this study aims to determine the teachers and parents perception on TPM-Kurtilas
Implementation at field (Amal Keluarga Kindergarten-Bandung). This study is part of a series researches on the adaptation of TPM to 2013 curriculum that conducted in multi years (three years) ranging from model improvement, pilot project, dissemination, and socialization held in Bandung, West Java - Indonesia. At this stage, TPM-Kurtilas is still in a pilot project and has conducted in various studies and viewed from different aspects. Among the research are: the Effectiveness of TPM-Kurtilas Implementation in Tunas Harapan Kindergarten, Bandung (Pratiwi, A., 2016); TPM-Kurtilas Adaptation in developing early childhood character (Listiana, A., \& Rachmawati, Y., 2016); The Effect of TPM-Kurtilas on Children's Behavioral Changes (Maryadi, B., 2016); Teacher's Perception on TPM-Kurtilas Implementation in Bunda Balita Kindergarten (Rachmawati, Y., 2016); TPM-Kurtilas Impact on Child's discipline (Puspadewi, 2016); TPM-Kurtilas Impact on Child's Polite Manners (Tsani, 2016).

This study is required to obtain data that will be used as a consideration in developing a better TPMKurtilas program in the future considering that TPM-Kurtilas is still in a pilot study.

\section{METHOD}

The method used in this research is qualitative method because the goal is to obtain the information of teachers' and parents' perception on the implementation of TPM-Kurtilas. The implementation process takes place every day in 30 minutes at the beginning of the learning. The program was held in four months (Feb-May 2016). The materials provided with regard to social and spiritual attitudes, Social attitudes include healthy behaviour, curiosity, creative, aesthetic, confident, disciplined, independent, caring, cooperative, adaptive, honest, humble, and polite. The spiritual attitude includes the acceptance of the teaching espoused. The data collection techniques used interview, teacher's field note, a questionnaire completed by the teachers. The study was conducted in Amal Keluarga Kindergarten, in Cigugur Girang village - Bandung, West Java. The data sources are interview of the principals who takes a role as the teacher also, and two teachers. The Analysis of datais using thematic analysis that provides some report which emphasizes on the answers to research questions then the data described narratively. 


\section{RESULTS AND DISCUSSION}

The findings based on the teacher's field note and reflection's checklist from the implementation of TPM-Kurtilas in Amal Keluarga Kindergarten Bandung obtained the following results.

\section{The Advantage of TPM-Kurtilas for the Teachers} After the implementation of TPM-Kurtilas in Amal Keluarga Kindergarten for about four months (Feb-May), the teachers were asked to give their responses by filling out the teacher's reflection questionnaire. The findings showed that the principal and teachers said that TPM-Kurtilas has made a better change for their school (Reflection of Mrs.Imas, Mrs. Tia and Mr. Agus, June 26, 2016). Based this reflection findings revealed that the presence of TPM-Kurtilas becomes new knowledge input for teachers to develop children's character at school. Furthermore the teachers also feel helpful by its detailed and focused program on building children's character. They also stated that this TPMKurtilas could become a reference and continously implemented in Amal Keluarga Kindergarten in subsequent years. Below is the quotation from teacher's reflection:

“...the presence of this program (TPM-Kurtilas) makes us feeling happy and grateful because through this activity certain changes are getting better, especially for me, I prepare the materials in a detailed and focus. This character program could also change children's character in a more targeted, increasing child's discipline and improving child's behavior. Hopefully, this program could an instructional reference in our kindergarten onwards". (Mrs.Tia \& Mrs. Imas, Tuesday, June 22, 2016).

It is reasonable that the teachers feel so helpful by TPM-Kurtilas program because commonly they mainly have had experience to draw up programs to develop children's cognitive rather than character's development. The condition is consistent to the teacher's observation conducted by several researchers which generally claimed that the teachers only provided learning materials for academic scopes such as on reading, writing, and counting/arithmetic (Mumun, 2009; Fuadah, 2013; Muhartini, 2013; Giyatni, 2013; Arie \& Rachmawati, 2014).

In addition, TPM-Kurtilas is doing in a systematic, planned, and sustainable certainly will make the teachers feel at ease and focus on achieving the goals and the objectives of character development. This opinion is in line with the statements from Hamalik (2003), Idi, A (2007) and Seknun (2014) which stated that the presence of design learning plans and strategies provided before teaching will make the learning objectives more easilyachieved.

\section{Children's Responses to TPM-Kurtilas}

Based on the teacher's fieldnote mentioned that the children's responses on TPM-Kurtilas implementation in their school are various and enthusiasthic in general. At first entering the class, children look so happy, showing delighted faces, moreover they are amazed (Mrs. Tia, Mrs. Imas \& Mr. Agus, Tuesday, March 22, 2016). Based on the teacher's fieldnote revealed that the children are excited because the teachers greet them in front of the classand change the class setting which make them comfortably in learning. This changing is in carpeted floors, new wall painting, locker, shoe rack, chair and table which sticked children's photographs on it. The teacher's field note reflected that the teachers and even the students are eager to go to school. Below is teacher's fieldnote in corresponds to this condition.

"The children were delighted with this class setting, carpeted floors, locker, shoe racks and even tables which sticked children's photograph on it" (Mrs. Imas, Monday, March 21, 2016).

Here is supported teacher's fieldnote:

"It is the first day for kindergarten's children finding out their new classroom, they feel so excited and delighted. The classroom atmosphere becomes so cool and comfortable. This condition motivates the teachers to come earlier and more active to teach the children" (Mrs. Tia, Monday, March 21, 2016).

Below is teacher's reflection note:

"When welcoming the students, the children feel so surprised seeing their new classroom setting starting from carpeted floors, bag's locker, shoe racks,...moreover when seeing the green carpet, children directly run here and there and some of them are lying on it" (Mr.Agus, March 22, 2016).

Supported by its welcoming school, the school situation makes children so comfortable and happier to go to school.

\section{TPM-Kurtilas Positive Impact to The Children}

Based on the teacher and principal's fieldnote showed that after TPM-Kurtilas implementation for four months at their school, the children become more disciplined, orderly, organized, and independent in performing their daily activities at school (Mrs. Imas, Mrs.Tia \& Mr.Agus fieldnote, April 25, 2016). The teachers stated that the attitude is seen clearly in children's daily routinity such as 
children can be directly lined up neatly, open and put their own shoes, store the bag on its place, mirror trims clothing on arrival and return (Mrs.Imas, Mrs.Tia \& Mr. Agus fieldnote). Only a small part of the children whose behavior has not shown a better change and still have to be reminded constantly by the teachers. Here is the quotation of their comments.

"...Children come to know the unknown, children who are less adjustable before this implementation program becomes more orderly at last. When they come to school, they directly say hello and put their own shoes on its locker, as a result they become more independent and not always depend on the teacher or parent" (Mr.Agus, June 29, 2016). condition.

Below are supported quotations for the above

"The children are started to become more orderly, when the bell is ringing, they line up immediately. When they enter the class, they also directly sit in a provided circle time area" (Mrs.Tia, March 24, 2016).

"When they come to school, they soon store the shoes on its provided rack. As they enter the class, they put their bags on their own locker. Only $10 \%$ of 21 children who still has changed yet and still have to be reminded as often as possible (Mrs. Imas, 26 \& 29 March, 2016)”.

The instructional which is designed by stages and using a variety of strategies as included on TPM-Kurtilas would be very helpful in developing children's character. The content of TPM-Kurtilas also provides some knowledge elements, and direct practice for its implementation. Therefore the children can get a direct impact from this program. Seknun, M. (2014); Setiawan, D. (2013); Nurchotimah, S. (2013); Stiles (in Hidayatullah, 2010) stated that this character education process should be conducted in stages starting from knowing the good, feeling and loving the good, and acting the good. In addition, TPM-Kurtilas which is designed in systematic, gradual, and sustainable has given positive impact on children's behavioral development. Concerning that character education applied systematically and sustainably, the children then become emotionally intellegent (Wardani, 2010).

\section{The Poster's Role in Developing Children's Positive Behavior}

Based on the teacher's fieldnote, the presence of classroom changing and the availability of posters are very helpful in making children orderly. The existence of foot mark in line up area helps children to stay in line orderly. Besides that, giving the name and photo in each locker and shoe racks, make the children opening and storing the shoes and bags in the locker respectively. Furthermore, learning rules provided by the poster also greatly help children obey the rules at school. The following is quotation of teacher's comment.

"Children can enter the room with order, the line up place signed by the footmark so they can step on it and they will not line in a rush".

By the presence of Posters, children could follow the school's rules easily such as wearing their own shoes directly, sitting on their own chair and table respectively. (Mrs. Imas, March 28, 2016).

The visual cues poster 's usage in this character development can help children to better understand the instruction given. This happends because this visual cues poster could help children improving organizational skills, academic learning, communication, socialization, and self-control (Hawkins \& Clayton, 2011). Therefore, the use of visual cues poster become an important component in the effort to make children understanding an instruction easily. In this case, Murphy (2013) stated that children in learning an instruction requires a behavior that can be 'seen', so that they can internalize their feelings toward such behavior.

\section{CONCLUSIONS}

In general, teachers and principals gave positive feedback on the TPM-Kurtilas implementation at their schools. Teachers find it helpful and openminded especially in developing children's character. They assume that the presence of TPMKurtilas impact positively on children's behavioural changes. In addition, the posters usage and visual media in this character development program are helping children to understand the expected character development.

\section{REFERENCES}

Arie \& Rakhmawati, (2014).Upaya meningkatkan kecerdasan interpersonal melalui metode Cooperative play pada kelompok B di Daqu School International: Jurnal Penelitian PAUDIA

Branson, D., \& Demchak, M. (2010). Toddler Teachers' Use of teaching Pyramid practices. Early Childhood Special Education, 30(4), 196-208

Fox, L., \& Hemmeter, M. L. (2009).A program-wide model for supporting social emotional development and addressing challenging 
behavior in early childhood settings. In W. Sailor, G. Dunlap, G. Sugai, \& R. Horner (Eds.), Handbook of positive behavior support (pp. 177-202.). New York, NY: Springer.

Fox, L., \& Lentini, R. H. (2006). " You Got It!" Teaching Social and Emotional Skills. YC Young Children, 61(6), 36.

Fox, L., Carta, J., Strain, P. S., Dunlap, G., \& Hemmeter, M. L. (2010). Response to intervention and the pyramid model. Infants \& Young Children,23(1), 3-13.

Fox, L., Dunlap, G., Hemmeter, M. L., Joseph, G. E., \& Strain, P. S. (2003). The Teaching Pyramid: A Model for Supporting Social Competence and Preventing Challenging Behavior in Young Children. Young Children, 58(4), 48-52.

Fuadah, H.L. (2013). Mengembangkan Kecerdasan Spiritual Anak Usia Dini melalui Pembelajaran dengan Metode Cerita Islami. (Skripsi). Fakultas Ilmu Pendidikan, UniversitasPendidikan Indonesia, Bandung.

Giyatni, (2013). Mengembangkan kecerdasan interpersonal melalui metode bermain peran pada kelompok B melalui metode Bermain Peran TK Al Irsyad.Jurnal Publikasi: Surakarta Universitas Muhammadiyah

Hamalik, O. (2003). Pendekatan baru strategi belajar mengajar berdasarkan CBSA. Bandung: Sinar Baru Algesindo

Hawkins \& Clayton. (2011) Using Visual Cues toImprove Classroom Instruction for Young Children with Developmental Delays. Atlanta: Assistive Technology Dept. Fulton County School.

Hemmeter, M. L., \& Fox, L. (2011). The Teaching Pyramid: A model for the implementation of classroom practices within a program-wide approach to behavior support. NHSA DIALOG, 12(2), 133-147.

Hemmeter, M. L., Ostrosky, M., \& Fox, L. (2006). Social and emotional foundations for early learning: A conceptual model for intervention. School Psychology Review, 35(4), 583.

Hemmeter, M. L., Ostrosky, M., Fox., L (2006). Social and emotional foundations for early learning: A conceptual model for intervention. School Psychology Review, 35(4), hlm. 583601

Hidayatullah, M.F. (2010). Pendidikan Karakter: Membangun Peradaban Bangsa. Surakarta: Yuma Pustaka

Humaida, C. (2013). Pendidikan karakter tingkat TK di Kabupaten Ponorogo tahun ajaran
2012/2013.Ponorogo :Universitas

Muhammadiyah Ponorogo.

Idi, A. (2007). Pengembangan kurikulum teori dan praktek. Yogyakarta: Ar Ruz Media.

Komnas Perlindungan Anak Indonesia.(2014). Kasus Bullying dan Pendidikan Karakter. Tersedia [Online]: http://www.kpai.go.id/berita/kpai-kasusbullying-dan-pendidikan-karakter/ [06 Agustus 2016]

Listiana, A., danRachmawati, Y., (2016). Pengembangan Model TPM-Kurtilas : Adaptasi Teaching Pyramid Model dalam Kurikulum 2013 Guna Pengembangan Karakter Anak Usia Dini. Bandung: PGPAUD UPI

Listiana, dkk (2016).Pedoman Umum Program Pegembangan Karakter Melalui teaching Pyramid Model Berdasarkan Kurikulum 2013. Bandung: Universitas Pendidikan Indonesia.

Listiana. (2013). Layanan bimbingan dengan menggunakan model pembelajaran piramid dalam meningkatkan kompetensi sosial anak. Bandung: Disertasi Bimbingan Konseling

Maryadi, B., Listiana, A. (2016). Penerapan TPMKurtilas terhadap perubahan perilaku anak. Bandung: PGPAUD UPI.

Muhartini. (2013). Artikel; PembinaanKecerdasan Interpersonal PadaAnakUsia (4-6 Tahun) TK LKIA II Pontianak

Muhtadi, A. (2010). Strategi Mengimplementasikan Pendidikan Budi Pekerti Yang Efektif Di Sekolah. Dinamika Pendidikan No.01/Th.XVII/MEI

Mumun, S. (2009).Pengembangan kecerdasan interpersonal anak. (Skripsi). Sekolah Tinggi Agama Islam Negeri, Pekalongan.

Murphy (2013). The Power of Visual learning and Storytelling in Early Childhood Education. Boston: Pearson.

Nata, A. (2013). Revitalisasi pendidikan karakter untuk mencetak generasi unggul. Jurnal Didaktika Religia, Vol. 1 No. 1

Nurchotimah, S. (2013). Implementasi kurikulum pendidikan berkarakter di sekolah. Seminar Internasional evaluasi pendidikan (SNEP) I Th. 2013

Olim, A.(2010). Mencari metode pendidikan karakter untuk PAUD :Belajar berbasis layanan (service learning). Proceedings of the 4th international conference on teacher education: join conference UPI \& UPSI. 
Pratiwi, A., Listiana, A. (2016). Efektivitas dama meningkatkan karater dasar anak di TK Tunas Harapan. Bandung: PGPAUD UPI

Puspadewi, D., Listiana, A. (2016). Profil kedisiplinan anak TK Yayasan Amal Keluarga setelah diterapkan program pengembangan karakter dasar TPM-Kurtilas.Bandung: PGPAUD UPI

Rachmawati, Y. dan Listiana, A., (2016). Pandangan guru terhadap implementasi Program TPMKurtilas di TK Bunda Balita, Kotamadya Bandung. Bandung: PGPAUD UPI

Ratnasari, D. (2015). Korelasi hasil penerapan pendidikan karakter dan standar tingkat pencapaian perkembangan anak dikelompok bermain batik sidoarjo. Journal Plus Unesa, Vol. 4 No.1.

Seknun, M.Y. (2014). Telaah kritis terhadap perencanaan dalam proses pembelajaran. Lentera Pendidikan, Vol. 17 No.1 Juni: 80-91.

Setiawan, D. (2013). Peran Pendidikan Karakter dalam Mengembangkan Kecerdasan Moral. Jurnal Pendidikan Karakter,Th III No. 1 Februari.

Tsani, N.A., Listiana, A. (2016). Profil sikap sopan santun anak TK Bunda Balita setelah diterapkan program pengembangan karakter dasar TPM-Kurtilas. Bandung: PGPAUD UPI

Undang-undang No. 17 Tahun 2007. Rencana Pembangunan Jangka Panjang Nasional

Undang-undang No. 20 Tahun 2003 tentang Sistem Pendidikan Nasional.

Undang-Undang RI. (1945). Teks Pembukaan.

Wardani, K. (2010). Peran Guru Dalam Pendidikan Karakter Menurut Konsep Pendidikan Ki Hadjar Dewantara. In Proceeding of The 4th International Conference on Teacher Education; Join Conference UPI \&UPSI (pp. 810).

Wiyono, H.( 2012). Pendidikan karakter dalam bingkai pembelajaran di sekolah.Jurnal Ilmiah CIVIS, Vol II No.2 Juli. 